\title{
O POSITIVISMO JURÍDICO: UMA ALTERNATIVA VIÁVEL PARA A EFETIVAÇÁO DOS DIREITOS HUMANOS E DO DIREITO AO MEIO AMBIENTE SUSTENTÁVEL
}

\author{
Kiwonghi Bizawu ${ }^{1}$ \\ Escola Superior Dom Helder Câmara (ESDHC) \\ Márcio Luiz Ribeiro Mota ${ }^{2}$ \\ Escola Superior Dom Helder Câmara (ESDHC) \\ Artigo recebido em: 17/10/2019. \\ Artigo aceito em: 26/11/2019.
}

\section{Resumo}

$\mathrm{O}$ presente estudo tem como objetivo pelos direitos humanos e ao direito analisar o positivismo jurídico na ambiental sob o prisma do positivismo obra de Norberto Bobbio como uma alternativa de defesa dos direitos humanos $\mathrm{e}$ do meio ambiente. Analisar-se-á o positivismo jurídico em sua vertente extremista e moderada, definindo os rumos a serem tomados para uma maior efetivação dos direitos fundamentais, entre dos quais o meio ambiente. Seráo contempladas as críticas feitas à visão do direito, à luta jurídico. Buscar-se-á a defesa de uma postura harmônica entre o positivismo jurídico e os direitos humanos e ambientais por terem o mesmo foco, mas vistos sob um ângulo diferente. Além disso, adotar-se-âo a pesquisa exploratória e o método dedutivo.

Palavras-chave: direitos humanos; meio ambiente; positivismo.

1 Mestre e Doutor em Direito Internacional pela Pontifícia Universidade Católica de Minas Gerais (PUC-MINAS). Professor de Direito Internacional na Graduação e do Mestrado em Direito Ambiental e Desenvolvimento Sustentável e Pró-Reitor do Programa de Pós-graduação em Direito na ESDHC. Membro do Núcleo Docente Estruturante (NDE). ORCID: https://orcid.org/0000-0003-2814-3639. E-mail: sebak_07@hotmail.com.

2 Mestre em Direito Ambiental e Desenvolvimento Sustentável pela ESDHC. Bacharel em Direito pela Faculdade de Direito Conselheiro Lafaiete (FDCL). Advogado. E-mail: marcio_mota@msn.com. 


\section{LEGAL POSITIVISM: A VIABLE ALTERNATIVE FOR THE EFFECTIVENESS OF HUMAN RIGHTS AND SUSTAINABLE ENVIRONMENTAL RIGHTS}

\section{Abstract}

The present study aims to analyze positivism in the works of Norberto Bobbio as an alternative of defending human rights and the environment. Analyze the legal positivism in his extremist and moderate aspect, defining the directions to be taken towards greater effectiveness of fundamental rights, among which, the environment. Will be referred to the criticism made to the vision of law, the fight for human rights and environmental law under the prism of legal positivism and human en environmental rights because they have the same focus, but seen from a different angle. Will be adopted to exploratory research and the deductive method.

Keywords: environment; human rights; positivism. 


\section{Introdução}

A teoria positivismo jurídico ao longo da história tem passado por várias críticas. Mesmo sendo apenas uma teoria, é capaz de gerar na doutrina adeptos e rivais fervorosos em busca da verdade absoluta. Sua principal característica é a consideração do Direito pelo que foi posto na palavra, ou positivado, a partir de um método científico. Ao referir-se ao positivismo, buscam-se estabelecer as noçôes de que o Direito é indissociável da autoridade daqueles que detêm poder político.

O Direito, portanto, passa a ser desenvolvido, nessa perspectiva, a partir de uma lógica que independe de outras searas externas ao Direito. Ao contrário, nega-se a própria existência de um direito natural, na medida em que as regras são criadas para composição do sistema jurídico - com consequentes criaçóes de obrigaçôes e direitos.

Com base nesse contexto, este estudo analisará o positivismo jurídico presente na obra de Norberto Bobbio (2006), um filósofo político italiano, que trouxe uma visão bastante didática do positivismo jurídico em sua obra $O$ Positivismo Jurídico: Liçóes de Filosofia do Direito.

Tal abordagem tem dois objetivos principais: o primeiro é desmistificar a visão do positivismo jurídico, comprovando que ele pode ser considerado uma teoria aplicável e, muitas vezes, mal interpretada mais por desconsideraçáo de seus postulados do que por sua própria argumentação teórica.

Ademais, objetiva-se, ainda, estudar os direitos humanos e o direito ao meio ambiente sustentável à luz do positivismo jurídico, tendo em vista as críticas recebidas pelos humanistas e ambientalistas, sem a pretensão de esgotar o tema proposto, porém, sugerindo uma corrente mais conciliadora e eclética - o que justifica o trabalho, em razão da necessidade de integraçóes teóricas que nos levem a novas experiências jurídicas, que acompanhem as realidades socioambientais, uma vez analisadas e interpretadas na transversalidade do meio ambiente na qualidade de direito com objeto próprio.

\section{0 positivismo jurídico}

Ao abordar o tema dos direitos humanos e do meio ambiente, nota-se que a visão do positivismo jurídico é, na maioria das vezes, criticada, tornando-se motivo de preconceitos e de rótulos a ponto de ser tratado de teoria "mal encarnada", do legalismo exagerado ou do extremismo de direita. Emprega-se uma série de adjetivos possíveis para classificar uma visão do direito que, muitas vezes, é ofuscada pelas críticas. 
Deve-se assinalar que tal crítica ao positivismo é fruto de falhas encontradas no processo de ensino e aprendizagem, pois se observam, nas primeiras aulas da graduação, a paixão e o zelo por parte de alguns professores, ao explicar o jusnaturalismo, despertarem nos alunos a curiosidade de aprofundar mais o antagonismo entre os jusnaturalistas e os juspositivistas no tocante àquilo que é justo ou injusto e àquilo que é universalmente válido ou inválido, àquilo que é e não é, àquilo que deve ser.

Tal apreciação sobre o positivismo, muitas vezes errônea, entre as teorias acaba sendo palco de discussôes entre os adeptos, tanto na graduação como na pós-graduação, com base na Teoria Pura do Direito do Hans Kelsen. A visão positivista do direito deve acarretar no meio acadêmico não apenas a valorização da ciência, mas também os princípios, as regras e as normas suscetíveis de abrigar os valores essenciais em que se funda uma sociedade com destaque no respeito aos direitos fundamentais, inclusive o direito ao meio ambiente como direito fundamental da terceira geração ou dimensão, conforme o entendimento doutrinário dos "apaixonados" do Direito. Desse modo, descarta-se a visão dogmática do positivismo que não reconhece outras realidades a não ser sua própria moldura normativa dentro da qual existem várias possibilidades de aplicação. Não se trata mais de construir uma teoria jurídica pura, mas sim de conciliar as tendências em Direito que o tornam uma ciência dinâmica.

Para Bobbio (2006, p. 224), as críticas vindas dos jusnaturalistas se referem principalmente a seus aspectos ideológicos, considerados responsáveis pela concepção estatolátrica do direito, no Brasil conhecida como uma posição de direita.

Vale ressaltar que o costume de dizer "de direita" ou "de esquerda" já denota ao intérprete o sentido de que a visão esquerdista é a errada, posto que a direção esquerda é a contramão da direção dos veículos adotada no Brasil e em muitos dos países, ou seja, um rótulo negativo para uma visáo ideológica da sociedade. Tal margem de interpretação torna-se, ao mesmo tempo, limitadora pela moldura.

Sendo assim, gera, automaticamente, a visáo de errado, de desvio de conduta, um verdadeiro preconceito às ideias que poderiam ser chamadas de socialistas, de revolucionárias e, por que não, de subversivas com respeito à ordem estabelecida em uma visão dualista de direito e de apreciação de normas.

Contudo, tal dualidade náo pode ser vista como superioridade de uma norma sobre a outra, menos ainda existir exclusão entre elas, mas uma relaçáo de independência, podendo ser, ainda, de interdependência.

É interessante observar que o positivismo é amplamente rotulado, assim como afirma Bobbio (2006, p. 225), sob alegaçóes de que, segundo seus críticos 
jusnaturalistas, é norteado pelo princípio de obediência incondicional à lei do Estado e pelas nefastas consequências que produziram os regimes totalitários.

Isso, táo somente porque a lei se torna a materialização principal de uma soberania popular que legitima e alicerça o Estado moderno. "O povo náo poderia ser apenas o autor da Constituição, mas tinha de ser o soberano, sem se deixar travar pela Constituição. A visão radical da soberania popular ganha espaço" (MENDES; COELHO; BRANCO, 2007, p. 176).

De acordo com Pierre Brunet (2005),

Em um primeiro sentido, "positivismo jurídico" refere-se a uma abordagem do direito, uma teoria do conhecimento jurídico ou metodologia segundo a qual o conhecimento da lei corresponde a uma atividade axiologicamente neutra. Pressupóe e baseia-se em separação de fatos e valores, de modo que o conhecimento da lei não exija nenhuma avaliação prévia, ou seja, o direito pode ser identificado sem avaliaçóes (BRUNET, 2005, tradução nossa). ${ }^{3}$

O positivismo pode ser abordado sobre vários aspectos, mas para analisá-lo em conjunto com os direitos humanos e ambientais, a didática de Bobbio é a mais adequada para este estudo, pois, para ele, o positivismo jurídico deve ser visto como método de estudo, teoria do direito e ideologia do direito, sendo que essas três formas são independentes.

A análise do positivismo como método para o estudo do Direito já produz uma separação que os críticos jusnaturalistas, muitas vezes, não percebem no momento em que o juspositivismo é separado do método positivista.

Nesse diapasão se situa Bobbio (2006, p. 234) quando observa:

Com efeito, a assunção do método positivista não implica também a assunção da teoria juspositivista. A relação de conexão entre o primeiro e a segunda é uma relação puramente histórica, não lógica, pois os primeiros estudiosos que aplicaram o método positivista viveram num contexto histórico-social (a Europa continental do século passado) no qual o direito era produzido exclusivamente pelo Estado.

Nesse sentido, torna-se necessário esclarecer a visão positivista, tendo em vista a importância dos debates acadêmicos, uma vez que o contexto histórico é o fator principal para fazer a distinção entre as diferentes correntes, sem olvidar

3 Dans un premier sens, "positivisme juridique" désigne une approche du droit, une théorie de la connaissance juridique ou encore une méthodologie selon laquelle la connaissance du droit correspond à une activité axiologiquement neutre. Elle présuppose et est fondée sur la séparation des faits et des valeurs, en sorte que la connaissance du droit n'exige aucune évaluation préalable, c'est-à-dire que le droit peut être identifié sans évaluations. 
as três maneiras de positivismo abarcadas na ideologia, na teoria do direito e na metodologia ou experiência jurídica. É dessa maneira que se pode chegar a um melhor entendimento sobre a validade de direito e a parte valorativa, ou seja, entender melhor o direito na vertente de ser e de dever ser.

Urge salientar didaticamente que o positivismo como método é a direção científica do direito, ou seja, o método científico necessário para se estudar a ciência política ou a teoria do direito, posiçáo defendida por Bobbio que encontramos em Kelsen seu expoente maior, no que se refere à ciência e ao direito:

Na firmação evidente de que o objeto da ciência jurídica é o Direito, está contida a afirmação - menos evidente - de que são as normas jurídicas o objeto da ciência jurídica, e a conduta humana só o é na medida em que é determinada nas normas jurídicas como pressuposto ou consequência, ou - por outras palavras - na medida em que constitui conteúdo de normas jurídicas. Pelo que respeita à questấo de saber se as relaçóes inter-humanas sấo objeto da ciência jurídica, importa dizer que elas também só são objeto de um conhecimento jurídico enquanto relaçôes jurídicas, isto é como relaçóes que são constituídas através de normas jurídicas (KELSEN, 2006, p. 79).

O estudo do positivismo jurídico como teoria do direito é amplamente discutido no meio acadêmico, mas ela náo pode ser negada, nem pela influência de Kelsen com sua teoria pura do direito, nem por todos que buscam desconstruíla, pois a argumentação tanto de defensores como de opositores é bastante fundamentada.

Acerca do supramencionado autor, importam consideraçôes sobre sua vida e obra, em razão da importância para a discussão que se propóe:

Hans Kelsen nasceu em 1881, na cidade de Praga, que na época fazia parte do Império Austro-Húngaro; veio a falecer em Berkeley, Estados Unidos, no ano de 1973, quando completaria 92 anos. Radicou-se em Viena aos três anos de idade, onde mais tarde (início do século XX) integrou um seleto grupo de intelectuais, conhecido como "Círculo de Viena". Obteve grau de Doutor em 1906, aos 24 anos, tendo conquistado o título de livre docente em Direito Público e Filosofia do Direito em 1911. No ano de 1934 publicou a sua primeira edição da obra Reine Rechtslehre - Teoria Pura do Direito e, em 1960, publicou a segunda edição com significativas mudanças em relação à anterior (VENDRUSCOLO, 2007, p. 99). 
O legado de Kelsen é incontestável, é uma visão do Direito que não está vinculada a um período de tempo ou contexto histórico, estando mais presente do que nunca no ordenamento jurídico internacional. Considera-se Kelsen, à luz de sua obra, da Teoria Pura do Direito, como o precursor do Direito Internacional, além de prever a criação de uma comunidade internacional em sua obra intitulada À Paz Perpétua, escrita em 1795.

Denota-se na obra supracitada que "a razão condena absolutamente à guerra" e que "o estado da paz é um dever imediato" que exige um esforço coletivo. É uma construção da coletividade oriunda da força da razão, e não do poder.

Importante ressaltar que há, ainda, o estudo do positivismo jurídico como ideologia, estando aqui inseridas as maiores discussóes acadêmicas, em que se desenham alguns tipos de obediência, a saber: a obediência ativa segundo a qual as regras devem ser obedecidas porque são justas; a obediência condicionada que retrata uma teoria positivista moderada que reconhece a legalidade como garantidora de valores específicos; a desobediência entendida como resistência na qualidade de reação à posição extrema do positivismo que prega a obediência às leis e que não conseguiu instaurar a paz entre as naçóes que por, duas vezes, experimentaram o sofrimento indizível com as duas Grandes Guerras Mundiais.

Há de se lembrar que, em caso de leis injustas, o jusnaturalismo moderado evoca a obediência passiva. Ambas as teorias, o jusnaturalismo e o positivismo, em certos aspectos, em matéria de leis e da criação legislativa, são diametralmente diferentes ou distintas, pois geram o confronto entre o monismo e/ou o dualismo.

Contudo, deve-se frisar a possibilidade de efetividade de Direito em matéria que envolve os direitos humanos e a normatividade ambiental para não considerar mais as duas correntes como antagônicas, mas conciliá-las com base na metodologia para regular, disciplinar e canalizar as condutas humanas, sobretudo no tocante à sustentabilidade quando se trata de equilíbrio do meio ambiente.

Não se trata mais de extremismo acadêmico, mas de uma aproximação para se chegar a uma simbiose entre a valoração e a interpretação oriundas das duas teorias que, aparentemente, eram vistas como antagônicas. A própria evoluçáo do direito leva irremediavelmente a um posicionamento moderado e racional desnudo de valor sentimental ou de juízo de valor, considerando a própria evolução da sociedade e da ciência.

É importante destacar que a valoração defendida pelos jusnaturalistas e a interpretação oriunda dos positivistas devem ser vistas como frutos de uma sociedade em transformação na Era dos Direitos preconizada por Bobbio (2004), em sua obra, A Era dos Direitos, acreditando serem os direitos frutos de uma evolução histórica, e não nascidos de uma única vez. 
Assim, Bobbio (2006, p. 225) assevera que, no tocante ao positivismo, por náo estar diante de uma doutrina científica, mas de uma doutrina ética do Direito, seria correto usar o termo positivismo ético ao se referir à ideologia juspositivista. Isso porque:

A vontade de Deus é - na doutrina do Direito natural - idêntica à natureza, na medida em que a natureza é concebida como tendo sido criada por Deus. Consequentemente, as leis que regulam a natureza têm, de acordo com essa doutrina, o mesmo caráter das regras jurídicas emitidas por um legislador: elas são comandos dirigidos à natureza; e a natureza obedece a esses comandos assim como o homem obedece às leis emitidas por um legislador (KELSEN, 1998, p. 13).

É de suma importância salientar que todo extremismo é prejudicial no campo das relaçóes humanas, podendo-se citar o fascismo na Itália, o nazismo na Alemanha, o comunismo na extinta Uniáo das Repúblicas Socialistas Soviéticas (URSS), bem como os outros regimes totalitários vigentes, que não aprendem com a história trágica da humanidade que, por duas vezes, com as duas Grandes Guerras Mundiais, viveu momento de sofrimento indizível.

Para Bobbio (2006, p. 227), existem quatro justificativas diferentes para a obediência absoluta à lei defendida pelo positivismo ético, a saber: a concepção cética ou realista da justiça, a concepção convencionista da justiça, a concepção sagrada da autoridade e a concepção do Estado ético.

Tais concepçôes são de fácil reconhecimento, pois seus atores são rapidamente identificados, mas não de modo a serem rotulados, porque quando existe o rótulo, há também o preconceito assentado em ideias desrespeitosas que, infelizmente, acarretam críticas severas contra o positivismo no tocante aos direitos humanos.

A concepção cética ou realista da justiça é a visão do mais forte, sendo considerado aquele que está no poder, ou seja, quem exerce o comando do Estado, ou grupo, é a lei, até que seja substituído por outro.

$\mathrm{Na}$ concepção convencionista da justiça, o valor está no que foi definido no ordenamento jurídico, ou seja, o que os homens definem como justiça, esta será a sua justiça. Bobbio (2006, p. 228) destaca a importância disso quando afirma:

Relativamente a esta concepção podemos falar de uma obrigação moral de obedecer às leis, pois estas encontram seu fundamento no pacto estipulado pelos consorciados, pacto sobre o qual se funda todo o direito e que, se não for observado, fará desmoronar todo o direito (e com ele a paz, que é o bem supremo do homem). 
A concepção sagrada da autoridade baseia-se no conceito das tribos e da monarquia, em que o líder ou rei tem o poder recebido de seus ancestrais ou concedido por um Ser Transcendental. Por meio dessa concepçáo, a verdadeira justiça surge das ordens do líder ou do monarca que encarna as forças da divindade.

Quanto ao Estado ético, nos moldes da filosofia política do Hegel, é um todo ético organizado, é uma unidade da vontade na universalidade e na individualidade ou subjetividade. Na realidade, Hegel propóe a passagem do Estado contratual para o Estado ético. O imperativo da vontade do criador absorvido por quem detém o poder sobre outros indivíduos pode acarretar o totalitarismo ou, ainda, o absolutismo em nome da razão do Estado.

Essa concepção, em particular, é mais divulgada pelos críticos do positivismo, pois essa visão é direcionada única e exclusivamente à verdade definida pelo Estado.

$\mathrm{O}$ ataque mais feroz ao positivismo baseia-se no julgamento de Nuremberg no qual os criminosos nazistas admitiram as atrocidades cometidas durante a Segunda Guerra Mundial, alegando ter cumprido as ordens da hierarquia. Essa visão extremista do positivismo é a bandeira defendida por seus críticos. Como se pode notar é apenas uma vertente extremista do conceito usado pelos advogados de defesa dos nazistas.

Para Bobbio existe uma "versão" moderada do positivismo ético, e não apenas a que eleva a figura do Estado ao patamar absoluto e imutável. Nas palavras do autor:

Concluindo: a versão moderada do positivismo ético difere da extremista porque, à diferença desta última, não diz que o direito é um bem em si, e antes o valor supremo, pelo que necessita-se sempre a ele obedecer, mas diz somente que o direito é um meio (em termos kelsenianos, uma técnica de organização social) que serve para realizar um determinado bem, a ordem da sociedade, com a consequência de que, se desejamos tal bem, devemos obedecer ao direito (BOBBIO, 2006, p. 232).

Dessa maneira, o positivismo jurídico, sem extremismos constitui uma maneira de pensar o Direito como ciência e, por mais que seja considerada a visão moderada ou fraca pelo próprio Bobbio, esta visão é a mais adotada nos debates acadêmicos quando se referem à defesa do positivismo jurídico.

\section{A questão da moral no positivismo jurídico}

Segundo Dimoulis (2006, p. 97-98), pode-se definir a moral como conjunto de conviç̧óes que, primeiramente, tem como objeto distinguir o bem do mal, 
orientando o comportamento dos indivíduos, na prática de se fazer o bem, permitindo avaliar as condutas individuais, impondo sançóes ao transgressor.

Discutir o que é moral se mostra uma tarefa muito árdua, pois existem muitas variáveis que devem ser consideradas como a cultura, a religião e muitos outros aspectos, mas para este estudo devemos abordar a relaçáo do direito com a moral.

A temática da separaçáo entre moral e o direito traz, segundo Dimoulis, (2006, p. 170), quatro equívocos que são atribuídos ao positivismo jurídico. O primeiro equívoco versa sobre a afirmação de que o positivismo nega qualquer influência da moral no direito, ou seja, têm uma visão suprema da lei afastando qualquer menção à moral, tendo em vista que muitas leis são baseadas nos costumes e a origem destes remonta uma visáo moral de alguma atividade da sociedade nela inserida, a moral não pode ser considerada como não influenciadora do Direito.

Segundo Dimoulis (2006, p. 170-171),

O legislador sempre possui uma "ideia" sobre o direito e a justiça, utilizando-a como fonte de inspiração e argumento de legitimaçăo. Aquilo que diferencia o juspositivismo da visão moralista é a afirmação de que o interprete/aplicador não pode modificar a decisão do legislador quando há divergência sobre a "ideia" de direito e de justiça. Confundir essas duas afirmaçōes leva a profundas polêmicas..

Assim, o positivismo jurídico não procura negar a influência da moral no Direito, mas não precisa estar vinculado a ela para existir. Outra questão abordada pelos críticos do positivismo informa que para os positivistas, o Direito deve sempre permanecer separado da moral.

$\mathrm{Na}$ realidade, os juspositivistas não afirmam que o direito deve ser separado da moral no sentido de um dever de ignorar ou mesmo de contrariar mandamentos morais. Isso carece de sentido. A teoria juspositivista procura separar o conhecimento do direito de sua avaliaçáo e das eventuais propostas de reforma, indicando que os juspositivistas, mesmo quando discordam pessoalmente de certas opçóes morais do legislador, não incorporam essa discordância, crença, indignação, reivindicação, etc (sic) em sua teoria que descreve o direito "como ele é" (DIMOULIS, 2006, p. 178).

Desse modo, na visão positivista o legislador pode utilizar valores morais ou não para se fazer uma norma não devendo estar obrigado a separar ou vincular a lei à moral na criação dela. Há uma separaçáo entre o processo de criação das leis e da aplicação destas. 
Assim, afirmar que o positivismo nega que os operadores do Direito possam decidir, conforme consideraçóes morais, é outro equívoco relacionado ao positivismo jurídico. No Código de Processo Civil, por exemplo, em seu artigo $126^{\circ}$ informa que, in verbis:

Art. 126. O juiz não se exime de sentenciar ou despachar alegando lacuna ou obscuridade da lei. No julgamento da lide caber-lhe-á aplicar as normas legais; não as havendo, recorrerá à analogia, aos costumes e aos princípios gerais de direito.

Vê-se, desse modo, a aplicação de outras maneiras de se julgar quando não houver normas legais para o caso. Procurar entender este artigo sob a ótica dos críticos do positivismo jurídico é como se houvesse a afirmação da impossibilidade de o positivista aceitar a norma como válida enquanto a realidade mostra que esta não somente é uma norma válida, como também visa trazer segurança jurídica aos que procuram a justiça, e não existe uma norma para aquele determinado caso.

De todo modo, apesar de reconhecer a realidade do ativismo judicial que faz parte das discussóes sobre o positivismo jurídico, descarta-se adentrar no assunto no presente artigo, menos ainda discutir sua validade no ordenamento jurídico pátrio.

Segundo Dimoulis (2006, p. 180),

$\mathrm{O}$ recurso à moral é autorizado, primeiro, quando o direito em vigor o prevê, incorporando em suas disposições referências morais; segundo, quando o legislador atribui ao aplicador poder discricionário, podendo esse último recorrer a critérios morais (como também a consideraçóes de oportunidade política ou de funcionalidade social).

Errado seria uma pessoa recorrer à sua ideia de moral para tentar corrigir uma norma válida, fazendo, dessa maneira, a própria justiça.

Outra afirmação levantada pelos críticos do positivismo é que ele reconhece incondicionalmente qualquer comando como jurídico. Essa visão deturpa toda a ideia de positivismo jurídico, pois acaba fazendo a caricatura de um indivíduo usando uma viseira animal, que o conduz sempre para uma mesma direção; nesse caso a viseira é para qualquer norma existente sem nenhum questionamento de sua validade.

Dimoulis (2006, p. 181), ao se referir ao positivismo utiliza o termo PJ stricto sensu e quanto a essa questão informa: 
O reconhecimento da juridicidade de uma norma não depende somente do fato de ser (subjetivamente e objetivamente) uma preposição de dever ser. Sabemos que o PJ stricto sensu exige que a norma satisfaça os requisitos de pertença ao sistema jurídico entre os quais se insere a exigência de concordância de conteúdo das normas (a norma inferior nâo pode contrariar o conteúdo da norma superior, incluindo exigências formais sobre o procedimento de sua criaçáo; a norma mais nova pode abolir a norma anterior do mesmo escalāo $(s i c)$ etc.

O autor afirma, ainda, que a definição da validade no juspositivismo é bastante exigente e, seguramente, não atribui juridicidade a qualquer comando. Concordamos com essa assertiva, posto que a análise de uma norma passe pelo exame de sua validade até mesmo para ela existir no ordenamento jurídico, sem ter a necessidade de ser substituída por outra a fim corrigir falhas nesta.

\section{0 mito do positivismo jurídico nazista}

Ao longo deste estudo, têm-se apresentado as críticas ao positivismo jurídico, talvez a maior e a mais deselegante formulada contra o mesmo é, certamente, o fato de tratá-lo de nazista ou de vinculá-lo à ideologia nacional-socialista, vigente na Alemanha no período ditatorial de Adolf Hitler.

Náo há como negar o rechaço e os preconceitos de que tem sofrido o positivismo jurídico. Algumas críticas são fundadas e outras não merecem crédito, sendo ingênuas e injustas por considerar o positivismo como pano de fundo de ideologias dos regimes ditatoriais ou totalitários. Nota-se, ainda, que, apesar dessa incompreensão, o positivismo tem recebido novas adesôes, o que demonstra sua relevância no mundo de Direito.

O filósofo alemão Radbruch, que, por causa de sua visão partidária diferente da nazista que assumiu o poder na Alemanha, foi demitido de seu cargo de professor catedrático onde lecionava, poderia ser apenas mais um alemáo que não compartilhava das ideias do regime, mas com o fim da guerra, voltou a lecionar na Alemanha defendendo a ideia de que o positivismo legitimou o nazismo.

Escreveu um artigo, em 1946, que ficou conhecido como fórmula de Radbruch, no qual comenta que essa concepção da lei e sua validade, a que chamam positivismo, foi a mesma que deixou sem defesa o povo e os juristas contra as leis mais arbitrárias, cruéis e criminosas. Tornam equivalentes, em última análise, o direito e a força, levando a crer que só onde estiver a segunda estará também o primeiro. ${ }^{4}$

4 Disponível em: http://direitoavista.blogspot.com.br/2011/04/cinco-minutos-de-filosofia-do-direito.html. Acesso em: 10 nov. 2014. 
Dessa maneira, o juspositivismo torna-se o objeto de ódio dos que são contra o nazismo, sendo essa vinculaçáo descabida e perigosa por gerar um mal-estar no meio acadêmico até meados da década de 1960. Dimoulis (2006, p. 259-260) afirma:

O juspositivismo é apresentado como teoria que traiu a causa do direito, como garantia (ou pelo menos tentativa) de pacificaçáo, justiça, solidariedade social etc., enganou os operadores jurídicos e ofereceu cobertura teórica a um regime criminoso. Essa tese traduz o espírito dos juristas alemães no período de desorientação política após a queda do regime nazista. A maioria dos juristas estava à procura de uma teoria do direito que pudesse condenar a barbárie e evitar sua repetiçăo.

O positivismo jurídico foi utilizado dessa maneira como "bode expiatório" para os erros do nazismo e essa ideia o acompanha até os dias atuais. $\mathrm{O}$ termo ficou conhecido como reductio ad hitlerum, e é utilizado para encerrar qualquer discussão, por exemplo, uma pessoa é ruim, logo uma pessoa gosta de Hitler; se a polícia age com violência, ela se parece com a Gestapo (polícia secreta nazista).

Dimoulis (2006) fez um estudo aprofundado sobre essa visão errada que se tem ao vincular o nazismo ao positivismo. Torna-se necessário, nesse caso, destacar alguns apontamentos suscetíveis de esclarecer as opiniôes mais críticas do positivismo jurídico.

Com a ascensão do regime nazista na Alemanha, não houve grandes modificações no ordenamento jurídico alemão, mas sim uma interpretação voltada para valores morais nazistas, usando uma interpretaçáo ideológica das leis e diferenciando totalmente da visão positivista.

A ideologia se baseava na aplicabilidade do Direito, tanto que os juízes eram obrigados a aplicar penas mais severas para servirem de exemplo para o povo. $\mathrm{O}$ discurso moralista era a posiçáo adotada pelo governo alemão, mas o moralismo era, na verdade, a propaganda nazista imposta como verdade absoluta.

Segundo Dimoulis (2006, p. 262), Schmitt, que era um dos principais ideólogos nazistas redigiu um trabalho dedicado à crítica do positivismo, acusando-o de todos os males do mundo jurídico, ao afirmar que o ordenamento nacional-socialista se baseava na união da lealdade, disciplina e honra, não podendo, assim, ser separado da direçáo unitária, sendo incompatível com o juspositivismo, que correspondia ao liberalismo, que tutela direitos individuais e garante a separação dos poderes em detrimento dos interesses da comunidade nacional. 
Se o maior teórico nazista fazia objeçóes ao positivismo e como sua visão estava totalmente vinculada à ideologia nazista, e esta era a corrente náo somente majoritária, mas também a única possível naquele país, podemos, então, chegar a três conclusões.

A primeira é que o nazismo não era a favor do positivismo jurídico, pois o ele busca a aplicação da lei, e não a interpretação que melhor atenda a interesses, no caso ideológico do nazismo.

A segunda é que Radbruch foi despedido pelo regime nazista. Deve ter sofrido humilhaçóes e perseguiçôes por ter uma visão partidária diferente da nacional-socialista e com o fim da guerra, defende justamente a crítica a uma teoria associando-a ao nazismo, permitindo, assim, a interpretaçáo de que o alvo de sua crítica não era o positivismo na verdade, mas sim o regime nazista.

E, em último lugar, a acusação de que o positivismo jurídico era defensor do nazismo não somente é infundada. Existe uma frase atribuída a Hitler em que ele diz que se uma mentira for dita várias vezes, pode se tornar uma verdade; foi isso que aconteceu com o positivismo jurídico.

\section{A luta pelos direitos humanos}

Os direitos humanos devem ser conquistados a cada dia, pois a humanidade buscou, pela convivência social e vontade de criar relaçôes harmoniosas entre os povos, a efetivação de seus valores éticos e morais antes mesmo da Declaração Universal dos Direitos Humanos de 1948, não obstante os tratados e convençôes internacionais. Apesar disso, a guerra e suas atrocidades continuam.

Comparato (2008, p. 226), pondera que, em termos técnicos, a Declaração Universal dos Direitos do Homem é uma recomendação que a Assembleia Geral das Naçóes Unidas faz a seus membros. Nessas condiçóes, costuma-se sustentar que o documento não tem força vinculante. Mas assevera:

\footnotetext{
Esse entendimento, porém, peca por excesso de formalismo. Reconhece-se hoje, em toda parte, que a vigência dos direitos humanos independe de sua declaração em constituiçôes, leis e tratados internacionais, exatamente porque se está diante de exigências de respeito à dignidade humana, exercidas contra todos os poderes estabelecidos, oficiais ou não (COMPARATO, 2008, p. 227).
}

Atualmente, o respeito aos direitos humanos alcançou o patamar de direito fundamental internacional, sendo considerados pelos que os buscam, como acima dos limites impostos pelas fronteiras dos países, pois a Declaração Universal, 
de 1948, busca a igualdade mundial por meio do respeito às diferenças, não protegendo a visáo imperialista que sempre dominou o mundo civilizado, mas a inclusão de todos como iguais nesse processo.

Não obstante, é importante pontuar que os direitos humanos surgem em uma perspectiva liberal, o que dificulta sua implementação por um caminho contra-hegemônico. Isso porque há uma estratificação de direitos fundamentais que se sobrepóem a outros na medida dos interesses dos Estados.

Ainda, de acordo com Comparato (2008, p. 228),

\begin{abstract}
Inegavelmente, a Declaração Universal de 1948 representa a culminância de um processo ético que, iniciado com a Declaração de Independência dos Estados Unidos e a Declaração dos Direitos do Homem e do Cidadão, da Revolução Francesa, levou ao reconhecimento da igualdade essencial de todo ser humano em sua dignidade de pessoa, isto é, como fonte de todos os valores, independente das diferenças de raça, cor, sexo, língua, religiáo, opinião, origem nacional ou social, riqueza, nascimento, ou qualquer outra condiçấo, como se diz em seu artigo II.
\end{abstract}

A maior dificuldade quando se analisa a luta pelos direitos humanos é sua afirmação, ou seja, seu reconhecimento, mesmo que a distinção entre o certo e o errado, o justo e o injusto estejam presentes na natureza humana e largamente defendida pelos jusnaturalistas, a realidade dos fatos infelizmente é outra.

Os direitos humanos são sufocados não só pelos regimes totalitários mencionados neste estudo, mas pelo homem, que se coloca na sociedade, não como antropocentrista, mas como ser individual. O que se diz, portanto, é acerca da existência de uma dificuldade de identificação do homem como ser coletivo, de direitos coletivos.

Essa diferenciação é pertinente, pois a visão antropocêntrica engloba todos os homens em detrimento da natureza, por exemplo, mas no caso dos direitos humanos, destacamos a ideia do individualismo exacerbado: o homem na qualidade de ser humano, escravizando, matando e tratando como seres abaixo dos animais que não têm consciência, os outros seres humanos. Trata-se do resultado da perspectiva liberal supramencionada.

A humanidade vive em um constante aprendizado. O contexto histórico trouxe a necessidade da reunião entre as naçôes, para tentar definir os rumos da sociedade. Podemos citar como exemplo, a Convenção para a Prevenção do Crime de Genocídio, em 1948, feita em um período pós-guerra, bem como as convençôes de Genebra, de 1949, sobre a proteção das vítimas dos conflitos bélicos, a Convenção de Viena sobre o Direito dos Tratados, sendo estes "como 
fonte de direito internacional e como meio de desenvolver a cooperação pacífica entre as nações, quaisquer que sejam os seus regimes constitucionais ou sociais", a Convenção de Viena sobre as Relaçôes Diplomáticas como contribuição para o desenvolvimento de relaçôes amistosas entre as naçôes, independentemente da diversidade de seus regimes constitucionais e sociais, conforme estipula o Preâmbulo da referida Convenção.

Segundo Comparato (2008, p. 30):

Em todos os níveis, da cosmologia à vida social, passando pela geologia e a biologia, o caráter evolutivo da realidade afirma-se sempre mais claramente. Ou seja, a ordem no universo só pode ser mantida por meio de um processo incessante de auto-organizaçâo, com a permanente adaptação ao meio ambiente.

Dessa maneira, a sociedade deve evoluir náo somente de acordo com suas necessidades, mas também reafirmando os valores humanos já consolidados que sempre necessitam de efetivação.

\section{$5 \mathrm{O}$ conflito de ideias entre o positivismo jurídico e os direitos humanos}

Como mencionado no início deste estudo, existe um conflito entre os defensores dos direitos humanos e os que defendem o positivismo jurídico, mas é importante salientar que o conflito é iniciado pelos defensores dos direitos humanos com seus discursos inflamados, enquanto os positivistas perguntam como vão fazer valer os direitos se não estão definidos na lei, e, assim, o debate fica acalorado.

A visão de que a defesa das leis está atrelada à aceitação cega dos ditames do Estado ainda aparece na sociedade. É curioso tal posicionamento, pois as leis passam pelo legislador, por voto da sociedade, logo é a sociedade por meio de seus representantes que definem as leis. Entáo qual seria o motivo do conflito, se tudo passa por um processo democrático e náo imposto pelos governantes?

A discussão perde um pouco da euforia no meio dos mais fervorosos críticos do positivismo jurídico quando são obrigados a aceitar a verdade que são as leis que definem a conduta do Estado. Por mais óbvio que pareça essa afirmativa, muitos teimam em criticar a abordagem dada aos direitos humanos, no âmbito internacional, sem pensar que para se fazer algo realmente significativo do ponto de vista prático, deve-se passar pelas leis.

Nessa perspectiva, os direitos humanos devem ser estudados em sua

5 Cf. Preâmbulo da Declaraçáo de Viena sobre o Direito dos Tratados (1969). 
imperatividade constitucional, superando-se, desse modo, o puro legalismo do positivismo jurídico ou normativista.

Assim, torna-se necessária a abordagem do direito ao meio ambiente como direitos humanos da terceira geração, direitos que envolvem a coletividade, visando à qualidade de vida e ao bem-estar social, tendo em vista a solidariedade. Considerando a titularidade coletiva, a defesa dos direitos humanos passa pela conscientização ambiental, sem se olvidar da necessidade de promover a relação inquebrantável entre o ser humano e a natureza da qual são extraídos os recursos que asseguram a vida.

No entender de Costa Hoshi (2012, p. 55):

A proteção do meio ambiente condiciona a proteção dos direitos fundamentais dos indivíduos, e qualquer dano provocado no ambiente ocasiona gravidade para cada indivíduo na Terra. Isto parece restar claro, de certo modo, ainda que algumas concepçóes na ordem jurídica internacional não estejam claras ou não tenham auferido o status de legalidade.

Pode-se concluir esta parte do estudo, ilustrando que o conflito de ideias entre o positivismo jurídico e os defensores dos direitos humanos está na dificuldade de implementação da temática humanista no ordenamento jurídico, em decorrência do processo legislativo disposto na Constituição Federal de 1988.

No entanto, os críticos preferem acusar os positivistas de extremismo a buscar mudança nas leis por meio de seus representantes, porque se os direitos humanos são violados, muitas vezes, é por causa do não cumprimento da lei e não da pretensa falta de segurança jurídica, uma vez que, no âmbito internacional, necessita-se de novas leis para as situaçóes que geram os conflitos em determinados países ou regióes mediante negociaçóes entre as partes - como tem ocorrido na Ucrânia após a anexação da Crimeia pela Rússia, gerando protestos da comunidade internacional.

Respeitam-se, todavia, as normas do direito internacional consuetudinário que são aplicadas para reger as questôes que não tenham sido expressamente reguladas pelas convençôes celebradas entre Estados.

\title{
60 direito ambiental na visão do positivismo jurídico
}

\author{
A Constituiçáo Federal de 1988, em seu artigo 225 disciplina que
}

Todos têm direito ao meio ambiente ecologicamente equilibrado, bem de uso comum do povo e essencial à sadia qualidade de vida, 
impondo-se ao Poder Público e à coletividade o dever de defendê-lo e preservá-lo para as presentes e futuras geraçôes, a proteção do meio ambiente está desta maneira positivada.

O debate maior sobre o direito ambiental, no que se refere às leis, reside na chamada cláusula de abertura presente no art. 30 da Carta Magna.

Tal artigo informa que compete aos municípios legislar sobre assuntos de interesse local e suplementar à legislação federal e a estadual no que couber, mas sobre a matéria ambiental a competência ficou estabelecida somente para os estados-membros, para a União e para o Distrito Federal com previsão no artigo $24^{\circ}$ da Constituiçáo de 1988.

Dessa maneira, o município não está autorizado a legislar sobre matéria ambiental, mas o artigo $30^{\circ}$ fornece o permissivo legal para fazê-lo de acordo com a corrente majoritária na doutrina, tendo como defensores Fiorillo, Milaré, entre outros.

Merece um estudo exaustivo a discussão sobre a competência dos municípios em matéria ambiental, mas, restringe-se, no momento, o debate entre positivistas e ambientalistas, pois, há de constatar que, na prática, a defesa do meio ambiente ocorrida em determinada regiáo carece de uma legislaçáo no local onde ocorreu o impacto ambiental. Tendo em vista a arquitetura federativa posta na CRFB $/ 88^{6}$.

Depreende-se desse fato a necessidade de os ambientalistas privilegiarem o diálogo político, sobretudo, nas audiências públicas ou nos tribunais, ou ainda se manifestarem por meio de ação popular em caso de dano ocorrido ou provocado em bem de uso comum do povo.

Lopes e Bizawu (2014, p. 103) destacam a importância da Ação Popular:

como instrumento do cidadão para prevenção e reparação do dano ambiental, sendo imprescindível a educação ambiental como ferramenta a fomentar a consciência ambiental, noticiando a disponibilidade da Ação Popular para a proteção do meio ambiente, bem comum do povo, cada dia mais transindividual e transnacional, legitimando-se qualquer pessoa para o ajuizamento dessa ação, enquanto sujeito de direitos e deveres, no papel de ator social agindo na proteção do meio ambiente, como patrimônio comum da humanidade.

Nesse caso, emendam que o autor popular deverá fazer a exposição dos fatos e fundamentos jurídicos que autorizam seu pleito, utilizando todo o arsenal jurídico disponibilizado pelo Direito Positivo, além da doutrina e jurisprudência que arrimam sua pretensão jurídica (LOPES; BIZAWU, 2014).

6 Vide Sarlet e Fensterseifer (2014). 
Devem-se, no entanto, considerar outros fatores que prejudicam a elaboração das leis que visam à proteção do meio ambiente nas audiências públicas para a implantação de uma determinada obra ou atividade, por exemplo, na maioria das vezes, a população não se interessa pela discussão e deixa ocorrer a destruição do meio ambiente.

As empresas prometem o progresso e muitos empregos para a regiấo. Com essa argumentação fortíssima, dificilmente a preservação pode prosperar, mas com uma legislação municipal bem estruturada, conhecendo os recursos naturais do município o impacto ambiental será bem menor. É uma maneira de preservar e proteger o direito das geraçóes futuras diante do dano iminente contra o meio ambiente, bem de uso da coletividade.

Para Vitoriano e Silva $(2011,139)$,

A proteção do direito das futuras geraçóes configura a proteção de um direito difuso ao longo do tempo e, considerando as premissas de direito ambiental, a imposição da reparação tem preferência em relação à indenização. A preferência da aplicação de medidas de natureza reparatórias e preventivas garantirá a manutençáo da qualidade ambiental e, via de consequência, o direito focado.

Nessa linha de raciocínio, com referência à Ação Popular supramencionada como instrumento para o exercício da cidadania com relação ao ambiente, a mesma autora observa:

Qualquer cidadão está legitimado a exigir do Poder Público o cumprimento do direito fundamental das geraçóes futuras, mesmo porque todos possuem, em potencial, vínculo afetivo e biológico com a geração vindoura. Esse sentimento de solidariedade e afetividade dá nome ao princípio e revela o seu fundamento. Desprovida de embasamento a limitação dos legitimados a exigirem o cumprimento do direito de indivíduos ainda inexistentes no mundo jurídico, considerando-se a natureza do direito envolvido e o interesse público na manutenção da integridade do planeta (VITORIANO E SILVA, 2011, p. 139).

Os críticos da visão positivista do direito afirmam que as leis beneficiam mais o empreendedor do que o meio ambiente, e este estabelecido com o art. 225 da Constituição Federal de 1988 foi elevado à categoria de direito fundamental, devendo estar acima de qualquer lei que possa prejudicá-lo. 
Nessa perspectiva, há de se ressaltar que o direito ao meio ambiente equilibrado é garantido a todos, com base na própria legislação que o positivou, dessa maneira, o positivismo jurídico não somente defende o meio ambiente como também consolida esse entendimento.

Sendo assim, a defesa do meio ambiente deve vir do ordenamento jurídico, logicamente discutido e analisado por toda a sociedade levando propostas a seus governantes. Wolfgang e Fensterseifer destacam o Princípio do Federalismo Cooperativo Ecológico no tocante à atuação conjunta das unidades federais entre si (União e estados-membros, no Brasil também o DF e os Municípios) quanto dos estados-membros entre si, com o intuito de permitir um planejamento e uma atuaçáo conjuntos e integrados em prol da consecução de objetivos comuns, do desenvolvimento e do bem-estar no plano mais amplo do Estado Federal sem afetar os níveis de autonomia de cada unidade da Federação. ${ }^{7}$

A maneira mais fácil de criticar é discordar de determinada situação sem buscar a solução legislativa. Fazer passeatas ou empregar outras formas de manifestação popular é altamente válido, como modo de conscientizaçáo da população, mas notam-se limitaçóes, pois a lei continua a mesma.

Todavia, a aplicabilidade do Direito em um Estado socioambiental requer a observância de normas éticas e jurídicas, uma vez que o agir comportamental do cidadão deve manifestar a vontade social e adequar-se à convivência social.

Para Vilas Boas Reis e Bizawu (2014, p. 68):

O cidadão é um sujeito ativo na organização da polis e deve se empenhar pela efetividade do desenvolvimento sustentável e pela promoçáo e difusão de conhecimento e valores para conservaçáo, recuperação e melhoria do meio ambiente com enfoque humanista, holístico, democrático e participativo.

Assim, o que é possível pontuar e concluir é que é importante a participação popular nas mobilizaçóes sociais acerca das pautas ambientais que englobam amplo espectro dos Direitos Humanos. Todavia, não se pode negligenciar a importância do regramento jurídico, na medida em que ele reflete a vontade do povo soberano de proteção ambiental. Desse modo, o positivismo jurídico aporta como uma estratégia para o enrijecimento da preservação e a vinculação de todos às normas de garantia da dignidade socioambiental.

7 Definição de Michael Kloepfer (apud SARLET; FENSTERSEIFER, 2014, p. 13). 


\section{Consideraçóes finais}

A relação do ser humano com a natureza requer uma verdadeira mudança paradigmática, pois sabe-se que, com o fim da visão antropocêntrica, o meio ambiente clama por uma proteção e preservação efetivas assegurada pela aplicabilidade das leis, visando à qualidade de vida de todos.

Analisou-se, neste trabalho, a relevância do positivismo presente na obra de Norberto Bobbio, assinalando que a corrente de pensamento positivista pode perfeitamente atuar nas discussóes de direitos humanos como também nas matérias referentes ao direito ambiental, promovendo-se, ao mesmo tempo, uma cooperação ecológica entre as unidades federadas entre si para possibilitar a elaboração de políticas públicas.

A busca pela efetivação dos direitos determina, dentro do federalismo cooperativo ecológico, as competências legislativas entre a União, os estados e o Distrito Federal, cabendo aos municípios, de conformidade com o art. 30, $\$ \$ 1^{\circ}$ e $2^{\circ}$ da Constituição da República de 1988 , legislar sobre os assuntos de interesse local. Tal exercício de competência concorrente se refere também à preservação do meio ambiente.

Trata-se da positivação de um dispositivo constitucional menos conflitivo com as demais unidades federativas em matéria ambiental, pois todas visam à efetividade, conforme o art. 225 da CRFB/88, do "direito ao meio ambiente ecologicamente equilibrado, bem de uso comum do povo e essencial à sadia qualidade de vida, impondo-se ao Poder Público e à coletividade o dever de defendê-lo e preservá-lo para as presentes e futuras geraçóes”.

A conservaçáo do meio ambiente depende, obviamente, da visão conciliadora e harmônica entre críticos e defensores do positivismo jurídico, pois a lei é a confirmação dos anseios do povo. E, por ser um marco normativo incontestável para a defesa e proteçáo ambiental, torna-se garantidora da qualidade de vida almejada pelo povo.

Nesse sentido, percebe-se que na luta pelos direitos fundamentais considerando-se o direito ao ambiente como direito fundamental e, para tanto, humano - é importante que os legisladores aprovem leis que regulem harmoniosamente as relações do ser humano com a natureza, evitando-se, assim, conflitos de interesse e buscando a prevalência da dinâmica evolutiva do direito ambiental. É uma questão de justiça e de ética ambiental.

A lógica do pensamento positivista moderado, ou seja, a busca pela normatização dos direitos, para que se tenha a segurança jurídica para cobrar sua 
aplicação, é a mesma meta de seus críticos, mas vista sob um ângulo diferente, podendo concluir-se, contudo, que ela náo é incompatível com os pilares normativos e axiológicos do direito ao meio ambiente.

\section{Referências}

BOBBIO, N. A Era dos Direitos. Rio de Janeiro: Elsevier, 2004.

BOBBIO, N. O Positivismo Jurídico: Liçóes de filosofia do direito. São Paulo: Ícone, 2006.

BRASIL. Constituição da República Federativa do Brasil. 1988. Disponível em: http://www.planalto.gov.br/ccivil_03/constituicao/constituicao.htm. Acesso em: 26 nov. 2019.

BRUNET, P. Norberto Bobbio et le positivisme juridique. In: COMANDUCCI, P.; GUASTINI, R. (Eds.). Analisi \& Diritto. Torino: Giappichelli, 2005. p. 159-170. Disponível em: https://halshs.archives-ouvertes.fr/halshs-00009757/ document. Acesso em: 26 nov. 2019.

COMPARATO, F. K. A Afirmação histórica dos Direitos Humanos. 6. ed. rev. e atual. São Paulo: Saraiva, 2008.

DIMOULIS, D. O positivismo jurídico: introdução a uma teoria do direito e defesa do pragmatismo jurídico-político. São Paulo: Método, 2006. (Coleção Gilmar Mendes, v. 2).

COSTA HOSHI, S. S. A Carta da Terra e o Princípio da integridade ecológica. Veredas do Direito, Belo Horizonte, v. 9, n. 17, p. 31-60, jan./jun. 2012.

KELSEN, H. Teoria pura do direito. 7. ed. São Paulo: Martins Fontes, 2006.

LOPES, A. L.; BIZAWU, S. K. Ação popular e dano ambiental: prevenção e reparação. Belo Horizonte: Arraes, 2014.

MENDES, G. F.; COELHO, I. M.; BRANCO, P. G. Gonet. Curso de Direito Constitucional. São Paulo: Saraiva, 2007.

REIS, E. V. B.; BIZAWU, S. K. Educação ambiental como processo para a construção da cidadania. In: COSTA, B. S.; REZENDE, E. N. (Orgs.). Temas essenciais em Direito Ambiental: um diálogo internacional. Rio de Janeiro: Lumen Juris, 2014, v. 4, p. 67-95.

SARLET, I. W.; FENSTERSEIFER, T. Notas acerca do Princípio do Federalismo Cooperativo Ecológico e do Correlato Princípio (e Dever) de Subsidiariedade. In: 
CAMPELlO, L. G. B.; SOUZA, M. C. S. A.; PADILHA, N. S. (Orgs.). Direito Ambiental no século XXI: efetividade e desafios. Belo Horizonte: Arraes, 2014. v. 3, p. 13-27.

VENDRUSCOLO, W. Consideraçóes sobre a vida e obra de Hans Kelsen. Revista Ciências Jurídicas e Sociais da Unipar, Umuarama, v. 10, n. 1, jan./jun. 2007.

VITORIANO E SILVA, M. O princípio da solidariedade intergeracional: um olhar do Direito para o futuro. Veredas do Direito, Belo Horizonte, v. 8, n. 16, p. 115-146, jul./dez. 2012. 